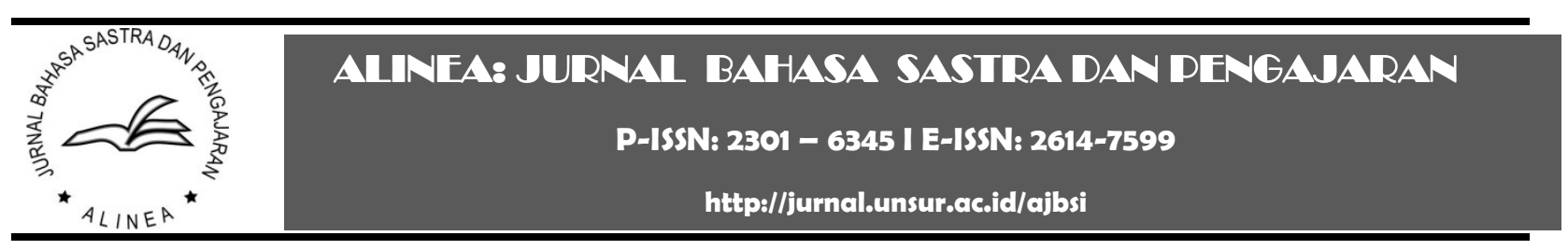

\title{
RAGAM KOLOKIAL PADA KEPOLISIAN RI
}

\author{
Farah Nabilah \& Gigit Mujianto \\ Universitas Muhammadiyah Malang, Indonesia
}

Riwayat artikel:

Dikirim: 20 Februari 2021

Direvisi: 5 Juli 2021

Diterima: 6 Juli 2021

Diterbitkan: 31 Oktober 2021

Katakunci:

kolokial, SPEAKING, semi

formal, dan formal

Keywords:

Colloquial, SPEAKING, Semi

Formal, and Formal Situations

Alamat surat

nabilahf747@gmail.com

\begin{abstract}
Abstrak:
Artikel ini akan mendeskripsikan variasi kolokial yang dipengaruhi faktor luar bahasa yang tedapat dalam interkasi SPEAKING. Metode deskriptif kualitatif digunakan dalam penelitian ini, dengan menitik beratkan peneliti sebagai instrumen penentu dalam penyelesian penelitian ini dengan deskripsi analisis terkait data. Data dalam penelitian ini berupa tuturan yang ditranskrip dari interaksi para penutur pada peritiwa turur tertentu. Teknik dalam penelitian ini yaitu deksriptif analisis yang digunakan untuk memaparkan penjelasan mengenai interaksi SPEAKING pada terapan variasi kolokial dalam bentuk tuturan yang ditranskrip. Hasil penelitian ini menujukkan penggunaan variasi bahasa kolokial yang ada dalam hierarki Kepolisian Republik Indonesia terdiri dari, (1) kolokial penghilangan huruf vokal dalam sebuah kata, (2) kolokial penghilangan huruf konsonan dalam sebuah kata, (3) penggunaan suku kata awal dan akhir pada sebuah kata, kemudian variasi bahasa kolokial dapat juga digunakan dalam situasi semi formal, dan formal.
\end{abstract}

\section{Abstract}

This article will describe colloquial variations that are influenced by external factors in the SPEAKING interaction. The qualitative descriptive method was used in this study, with the emphasis on the researcher as a decisive instrument in completing this study with a description of the analysis related to the data. The data in this study are utterances that are transcribed from the interactions of speakers at certain speech events. The technique in this study is the descriptive analysis which is used to explain the explanation of the SPEAKING interaction in the application of colloquial variations in the form of transcribed speech. The results of this study indicate the use of colloquial language variations that exist in the hierarchy of the Indonesian National Police consisting of, (1) colloquial omission of vowels in a word, (2) colloquial omission of consonants in a word, (3) use of initial and final syllables in a word. a word, then colloquial language variations can also be used in semiformal and formal situations.

\section{PENDAHULUAN}

Manusia merupakan pemegang peranan di muka bumi ini, dan bahasa memiliki peranan penting dalam kehidupan manusia sebagai alat untuk berkomunikasi dan berinteraksi dengan manusia lainya. Bahasa sebagai bentuk komunikasi yang bersumber dari pemikiran dan perasaaan seseorang yang kemudian dilambangkan untuk menyampaiakan ujaran atau pesan yang memiliki arti kepada orang lain. Faizah dalam (Hasanah, 2014:3) sependapat dengan uraian di atas yang mamaparkan bahwa sese-orang dalam berkomunikasi bertujuan untuk menyeseuaikan diri dengan lingkungan fisik serta sosialnya. Penggunaan bahasa memiliki penga-ruh pada suatu aktivitas manusia, hal ini disebabkan lantaran setiap seseorang melakukan aktivitas akan selalu melibatkan bahasa di dalamnya. 
Bahasa juga yang mampu membedakan manusia dengan makhluk lainya. Pola komunikasi yang terbentuk akibat paham bahasa dapat menunjukkan karakter dari penuturnya (Asmara, 2015:94).

Fenomena yang saat ini terjadi banyak penggunaan bahasa yang tidak mengikuti kaidah dalam berbahasa sebenarnya. Hal ini menyebabkan munculnya bahasa baru di antaranya terjadinya proses pemendekan suatu kata. Serupa dengan pengertian bahasa kolokial yang dikemukakan oleh (Muhidden, Amran, \& Optimaliti, 2016:130) merupakan bahasa yang dituturkan dalam sehari-hari di daerah tertentu. Bahasa kolokial dalam penggunaanya tidak mementingkan unsur-unsur kaidah dalam berbahasa. Hal tersebut terjadi lantaran yang terpenting ialah kefahaman antar penutur dan pendengar yang terlibat. Bahasa kolokial sendiri memiliki ciri utama yakni pemendekan kata dengan menghilangkan bagianbagian tertentu dalam kata.

Peristiwa tutur terjadi tentu saja tidak bisa lepas dari faktor luar bahasa. Faktor-faktor di luar tersebut memiliki kaitan di setiap peristiwa tuturnya terhadap bahasa. Faktor-faktor tergabung dalam teori SPEAKING yang dikemukakan oleh Hymes (Ibrahim, 2009: 12) sebagai berikut yang masing-masing bunyi merupakan fonem awal dari faktor-faktor yang dimaksudkan antara lain Setting dan sense berkaitan dengan waktu, tempat serta suasana bicara, Partisipan ialah penutur yang terlibat dalam peritiwa tutur, End atau tujuan dari peristiwa tutur tersebut seperti apa, Act ialah kesempatan yang digunakan penutur pada situasi tertentu, Key yakni nada suara serta ragam bahasa yang dipergunakan demi menyampaikan pendapatnya, serta cara mengemukakan pendapat, Instrument merupakan alat dalam berpendapat, Norma yaitu kaidah yang harus dipatuhi dalam peristiwa tutur, Genre ialah jenis kegiatan diskusi yang mempunyai sifat-sifat lain dari jenis kegiatan lain (Putry, 2016:16-17).

Pada penelitian sebelumnya yang memiliki kolerasi terhadap bahasan kali ini yang di dalamnya terdapat bahasan mengenai faktorfaktor di luar bahasa yang mempengaruhi peristiwa tutur. Tertuang pada artikel jurnal yang berjudul Etnografi Komunikasi: Sebuah Pendekatan Dalam Mengkaji Perilaku Masyarakat Tutur Perempuan Jawa oleh (Iswatiningsih, 2016) yang menjelaskan hadirnya pemakaian bahasa atau tuturan dalam masyarakat, sama halnya dengan fokus makalah ini yang membahas mengenai pemakaian bahasa atau tuturan yang lebih menuju pada suatu institusi negara. Pada penelitian sebelumnya yang dilakukan oleh Daroe Iswatiningsih objek penelitianya berpusat pada tindak tutur perempuan Jawa, yang menunjukkan gaya komunikasi perempuan jawa. Berbeda dengan bahasan kali ini yang mengambil fokus terhadap hierarki kepolisian negara Republik Indonesia, bagaimana bentuk sebutan yang digunakan oleh anggota penutur di dalamnya.

Fenomena penggunaan bahasa saat ini salah satunya dapat ditemui dalam refleksi bahasa kolokial yang terdapat pada hierarki kepolisian negara Republik Indonesia. Pada institusi kepolisian diterapkanya sistem hierarki dengan tujuan demi menjaga terlaksananya tugas kepolisian sebagai otoritas pemegang keamanan dan kertertiban, serta otoritas penegak hukum pengadilan (Nugraha, 2018:6). Hierarki sejalan dengan karier para anggota kepolisian, yang ditandai dengan pangkat. Pangkat atau jabatan di dalam organisai kepolisian merupakan penentu level kekusaan dalam institusi tersebut. Bahasa kolokial yang terlihat dalam hierarki kepolisian negara Republik Indonesia ditandai dengan pemendekan kata di setiap penyebutan pangkatan atau jabatan anggota kepolisian. Pada fenomena 
128 Alinea: Jurnal Bahasa, Sastra, dan Pengajaran Volume 10, (2) Oktober 2021, hal. 126-144

ini dapat dilihat juga peran faktor-faktor luar bahasa yang mampu mempengaruhi penyebutan suatu pangkat atau jabatan dalam institusi kepolisian.

Bahasan kali ini juga merujuk pada penelitian terdahulu yang memaparkan mengenai implementasi penggunaan bahasa kolokial. Penelitian terdahulu tersebut berjudul Penggu-naan Trunkasi Bahasa Kolokial Dalam Kalangan Pelajar oleh (Muhidden \&Arman, 2016), yang memiliki kesamaan dengan penelitian ini yang mengkaji bentuk pemendekan kata pada penuturnya. Berbeda dengan bahasan kali ini yang terfokus pada bentuk sabutan dalam hieraki kepolisan negara Republik Indonesia, penelitian yang dilakukan Zuraidah Muhidden dan Noorhanis Amran yang difokuskan kepada tiga golongan kata yakni kata nama, kata adjektif dan kata kerja.

Pada bahasan kali ini merujuk pada penelitian terdahulu yang memaparkan mengenai proses pembentukan kata asal atau awal yang mengalami proses morfologis. Proses morfologis sendiri menurut Tsujimura dalam (Nishfullayli, 1995:37) pembentukan kata dapat terjadi dengan 5 cara yang meliputi (1) afiksasi, penggabungan (compounding), (2) reduplikasi, (3) pemenggalan (clipping), (4) peminjaman (borrowing). Pada bahasan kali ini pembentukan kata yang terlihat menggunakan cara pemenggalan atau penghilangan kata. Pemenggalan atau penghilangan kata ialah proses penyingkatan yang menetapkan salah satu bagian leksem.

Berdasarkan pemaparan tersebut, bahasan kali ini dilakukan dengan tujuan untuk mengenalkan kepada orang awam ataupun anggota kepolisian yang baru dalam mengetahui pemendekan kata pada penyebutan pangkat atau jabatan di dalam hierarki kepolisisian negara Republik Indonesia. Bahasan kali ini diharpakan mampu memudahkan orang awam ataupun anggota baru mengenal pangkat atau jabatan di dalam hierarki kepolisisian negara Republik Indonesia.

\section{METODE}

Pada penelitian, data yang digunakan bersifat deskriptif, karena kosakata atau pembedaharaan kata dari para informan menjadi utama dalam penelitian ialah sumber deksripsi yang menujukkan proses perubahan kata pada penggunaan kolokial dalam hierarki kepolisian Republik Indonesia.

Penelitian dilakukan dengan melalui beberapa tahapan penelitian yang dilakukan oleh peneliti. Pada penelitian pendekatan yang digunakan merujuk pada pendekatan kualitatif dengan tujuan mengumpulkan data yang didapat dari hasil obeservasi peneliti terhadap tuturun yang terdapat di sejumlah video kanal Youtube yang memuat data yang relevan dalam penelitian. Sumber data dalam penelitian yakni informan yang berperan sebagai penutur dalam video yang dikumpulkan oleh peneliti.

Data yang digunakan dalam peneltian bersifat deskriptif, hal ini dikerenakan bentuk tuturan sapaan atau sebuatan dalam hieraki kepolisian Republik Indonesia memerlukan penjabaran yang mampu memaparkan proses pembentukan kata dengan berdasarkan prinsip kolokial dengan memperhatikan faktor-faktor di luar dalam suatu peritiwa tutur. Data dalam penelitian diperoleh dengan teknik rekam catat. Peneliti mengumpulkan data dengan menyaksikan video yang memuat data kemudian mencatat tuturan yang menjadi data dalam penelitian.

Teknik yang digunakan dalam penyele-saian penelitian yakni deskriptif analisis. Peneliti menggunakan video yang terdapat di kanal youtube sebagai sumber data. Informan dalam penelitian berperan sebagai penutur dalam video pilihan peneliti, kemudian dilakukan analisis terhadap tuturan yang menjadi data dalam penelitian. 
Pada penelitian, objek yang digunakan adalah sebutan atau sapaan dalam hierarki Kepolisian Republik Indonesia yang menjadi penentu level sesorang dalam instansi tersebut. Analisis pada penelitian dilakukan secara kualitatif. Aktivitas dalam penelitian ini melalui tahap yakni indetifikasi data, pemaparan data, dan simpulan. Peneltian dilakukan dengan tujuan mengidentfikasi bahasa kolokial dalam hierarki kepolisian Republik Indonesia.

\section{HASIL PENELITIAN}

\section{Proses Pembentukan Kata}

Proses pembentukan kata terdiri dari lima cara, yakni: afiksasi, penggabungan (compounding), reduplikasi, pemenggalan (clipping), dan peminjaman (borrowing). Pada bahasan kali ini pembentukan kata yang akan dibahas yakni pemenggalan atau penghilangan kata. Pemenggalan atau penghilangan kata ialah proses penyingkatan yang menetapkan salah satu bagian leksem. Berikut pemaparan mengenai pembentukan kata yang menyebabkan varisai baru dalam penggunaan sebutan di dalam hierarki Kepolisian Republik Indonesia seperti yang disebutkan dalam (Awlia, 2019). Berdasarkan hasil obeservasi peneliti menemukan tiga variasi bahasa kolokial yang memperoleh pengaruh dari faktor-faktor di luar bahasa yang terdiri dari:

\section{Penghilangan Huruf Vokal dalam Sebuah Kata}

Interkasi SPEAKING merupakan faktor di luar bahasa yang mampu mempengaruhi peristiwa tutur. Interaksi SPEAKING ini merupakan suatu rangkaian proses yang mampu menghasilkan suatu tindak tutur yang apabila dikaitkan dengan variasi bahasa kolokial sangatlah relevan lantaran pada prinsip kolokial yang menuntut suatu kata mengalami perubahan tentu saja tidak lain merupakan bentuk dari impersi faktor di luar bahas yang tegabung dalam interkasi SPEAKING. Berikut akan dipaparkan mengenai terapan interkasi SPEAKING pada variasi bahasa kolokial yang mengalami penghilangan huruf vokal.

\section{Bharada (Bhayangkara Dua)}

"Satu anggota Brimob dari kelapa dua Depok Jawa barat Bharada (Bhayangkara Dua) Doni Priyanto gugur dalam kejadian kontak senjata yang berlangsung selama dua setengah jam ini.“

Pada data di atas suasana yang tergambar ialah suasana duka lantaran bertepatan dengan terjadinya peristiwa tewasnya seorang anggota kepolisian yang disebut lengkap dengan jabatan yang ia emban yakni Bahrada. Data tersebut dikemukakan oleh presenter berita secara lisan pada siaran televisi swasta dengan menyesuakian isi berita, nada serta ragam bahasa yang digunakan menujukkan rasa duka walapun tetap dibalut dengan gaya bahasa berita yang terkesan formal. Pelaku tutur dalam data ini menujukkan impresi dalam bertutur dengan penyebutan jabatan atau pangkat seseorang yang sedang dibicarakan serta menunjukkan rasa empatinya melalui nada serta ragam bahasa yang digunakan dalam

Sapaan pada pangkat atau jabatan Bahrada yang dilakukan oleh penutur dalam data ini telah mengalami proses pembentukan. Hal ini ditandai oleh penghilangan huruf vokal $\mathrm{u}$ yang menyebakan penyingkatan kata dari kata sebelumnya.

\section{AIPDA (Ajun Inspektur Polisi Dua)}

"...kepolisian masih terus mencoba mengungkap apakah motif dari penembakan ini mirip dengan yang terjadi dengan penembakan terhadap 
anggota kepolisian sebelumnya misalnya di Jakarta pusat, AIPDA (Ajun Inspektur Polisi Dua) Patah Saktiyono yang mengalami luka tembak..."

Data di atas yang berperan sebagai pelaku tutur yakni reporter berita yang berusaha menginformasikan mengenai permasalahan yang terjadi secara lisan. Pembawaan yang diperlihatkan oleh reporter berita tersebut disesuakian dengan gaya bahasa yang formal. Pelaku tutur dalam data ini memperoleh kesempatan untuk menginformasikan apa yang telah diperoleh setelah melalui arahan presenter berita yang berada di studio televisi yang sedang menayangkannya secara live. Norma yang ditunjukkan oleh pelaku tutur ini terlihat dari pengucapan atau pelafalan yang disampaikan oleh pelaku tutur pada saat menyebutkan nama seseorang yang disertai oleh pangkat atau jabatan di depannya, sebagai bentuk rasa hormat pelaku tutur terhadap kedudukan sesorang.

Vokal $u, e$, dan $o$ pada penggunaan saapan yang dilakukan oleh penutur mengalami penghilangan terhadap pangkat atau jabatan AIPDA. Hal ini dilakukan oleh penutur lantaran kepraktisanya seperti yang dianut oleh prinsip kolokial tanpa merubah makna sebenarnya.

\section{BRIPDA (Brigadir Polisi Dua)}

“...ada BRIPDA (Brigadir Polisi Dua) Ahmad Maulana dan AIPTU (Ajun Inspektur Polisi Satu) kushendratna yang tewas pada kejadian tersebut."

Pelaku tutur pada data di atas merupakan presenter berita yang berusaha menginformasikan atas peristiwa tewasnya anggota kepolisian. Berita terebut disampakan secara lisan dengan bahasa berita yang formal dengan nada yang sedikit merendah. Norma atau etika yang ditunjukkan oleh pelaku tutur telihat dari bagaimana presenter berita tersebut menyebut nama seseorang dengan mengikutsertakan sebuah gelar, kemudian dapat juga dilihat dari nada serta ragam bahasa yang mengisyaratkan bahwa terjadi sesuasana duka.

Pada percakapan yang dilakukan oleh penutur terdapat sapaan atau jabatan yang terucap yakni BRIPDA. Sapaan atau jabatan tersebut mengalami proses perubahan kata yang ditandai dengan penghilangan huruf vokal u dan o pada kata awal yang memiliki tujan untuk mempersingkat penyampaiannya dan mempermudah penuturnya .

\section{BRIPKA (Brigadir Polisi Kepala)}

"Terkait penembakan yang menewaskan BRIPKA (Brigadir Polisi Kepala)Sukardi Selasa malam 10 September mabes polri menggelar konfersi pers, dan untuk mengatahui perkebanganya sudah ada satu reporter karlos maikel di mabes polri.“

Data di atas merupakan berita yang berisi informasi mengenai meninggalnya seseorang yang tegabung dalam institusi kepolisian. Data tersebut disampaikan oleh pelaku tutur yang merupakan presenter berita secara lisan di sebuah acara berita stasisun televisi swasta. Berita tersebut disampaikan dengan formal dan ditandai dengan nada yang mengisyarkatkan kabar duka. Norma dalam data ini diperlihatkan oleh pelaku tutur sebagai tanda bentuk rasa hormat tehadap prosesi sesorang dengan mengisyaratkan jabatan atau pangkat seseorang yang sedang dibicarakan.

Pada penggunaan sapaan terhadap jabatan anggota kepolisian dengan "BRIPKA" yang disampaikan oleh penutur, merupakan pemendekan kata yang telah mengalami proses perubahan kata. Hal tersebut ditandai dengan penghilangan huruf vokal $o$ dan $e$. Adapun perubahan sapaan atau panggilan tersebut lataran kepraktisan dalam pengucapanya. Hal ini membuktikan kesesuain dengan prinsip 
variasi kolokial yang mengedepankan segi kepraktisan dalam pengucapan oleh penutur.

\section{AIPTU (Ajun Inspektur Polisi Satu)}

“...ada BRIPDA (Brigadir Polisi Dua) Ahmad Maulana dan AIPTU (Ajun Inspektur Polisi Satu) kushendratna yang tewas pada kejadian tersebut."

Pada data di atas diperoleh dari peristiwa tutur yang melibatkan presenter dan reporter berita sebuah acara stasiun televisi swasta. Reporter sebagai pelaku tutur dalam memperoleh kesempatan untuk melakukan peritiwa tutur setelah mendapat intruksi dari presenter berita. Berita tersebut disampaikan dengan ragam bahasa dan gaya khas berita yang formal. Berita ini merupakan kategori informasi yang berusaha disampaikan oleh penutur. Pada di ini terlihat etika yang ditunjukkan oleh pelaku tutur yang menyebutkan nama dengan menyertakan pangkat atau jabatan yang diemban oleh anggota kepolisian yang tewas.

AIPTU merupakan penyebutan sapaan atau jabatan yang dilakukan oleh penutur terhadap seseorang yang sedang dibicarakan. Hal tersebut tentu saja mengacu pada seseorang yang terlibat dalam hieraki kepolisian. Pada sapaan tersebut telah mengalami proses perubahan kata dengan adanya penghilangan huruf vokal $e$. Hal tersebut terjadi lantaran sesuai dengan prinsip kolokial yang mempersingkat ujaran sebenarnya agar lebih praktis dalam pengucapannya.

\section{Ipda (Inspektur Polisi Dua)}

"Ipda (Inspektur Polisi Dua)Anumerta auzar sore dimakamkan di tempat pemakaman umum Mayang Sari bambu kuning raya Pekanbaru."

Data di atas memperlihatkan suatu peristiwa tutur yang palaku tutunya ialah seorang presenter berita. Presenter berita ini berusaha menyapaikan informasi berupa berita duka dari institusi kepolisian dengan nada yang sedikit merendah dan tentu saja menggunakan bahasa formal secara lisan. Penyebutakan pangkat atau jabat yang dilakukan oleh peristiwa tutur merupakan bentuk etika yang dikemukan oleh pelaku tutur lantaran rasa hormatnya akan kedudukan seseorang dalam bidang profesinya.

Pada data bentuk sapaan Ipda yang berasal dari penutur ini mengalami proses perubahan kata dengan prinsip kolokial di dalamnya. Proses perubahan kata pada data ini dilihat dari penghilangan huruf vokal u, e, dan o. Prinsip kolokial pada data ini bisa dilihat dari penyingkatan kata dari kata aslinya.

\section{KOMPOL (Komisaris Polisi)}

“...tapi polri tetep pernah memberikan surat ya surat pembatalan artinya surat kepada KPK bahwa untuk KOMPOL (Komisaris Polisi) Rossa tidak ditarik dan kemudian juga artinya bahwa sampai saat ini kita juga belum belum menerima surat tersebut dari KPK."

Pada data di atas pelaku tutur yang berperan yakni seseorang yang tergabung dalam institusi kepolisian. Pelaku tutur tersebut berusaha memberikan keterangan terkait peristiwa yang sedang dibicarakan secara lisan. Tuturan yang dikemukakan oleh pelaku tutur terjadi lantaran adanya partispan lain yang berperan sebagai reporter yang meminta keterangan pada pelaku tutur. Ragam bahasa yang digunakan dalam peristiwa tutur ini tergolong pada kategori bahasa semi formal. Bentuk etika yang diperlihatkan oleh penutur terlihat dari penyebutan pangkat atau jabatan teman sesama rekan dalam institusi kepolisian.

Pada hireraki kepolisian terdapat sebuah paangkat atau jabatan yang dijadikan sebagai bentuk sapaan. Terdapat pangkat atau jabatan KOMPOL. Pada data ini penggunaan sapaan 
KOMPOL yang dilakukan oleh penutur mengalami perubahan kata menjadi lebih singkat yang ditandai oleh hilangnya huruf vokal seperti a dan $i$.

\section{AKBP (Ajun Komisi Besar Polisi)}

“...tertanggal 2 September 2019 Kapolres Pekalongan kota yang lama AKBP (Ajun Komisi Besar Polisi) Ferry sandi Sitepu diangkat dalam jabatan baru sebagai wakil direktur kepolisian perairan dan udara atau Wadir polair Polda Jateng."

Pada data di atas yang berperan sebagai pelaku tutur yakni presenter berita stasiun televisi swasta. Pembacaan berita ini bertujuan menginformasikan atas amanah baru yang diemban oleh seorang anggota kepolisian. Nada serta Ragam bahasa yang digunakan dalam peritiwa tutur ini setabil dengan sifat formal. Penyebutan pangkat atau jabatan yang dilakukan oleh penutur merupakan bentuk rasa menghargai pada suatu kedudukan di dalam profesi seseorang.

AKBP merupakan bentuk sapaan terhadap sesorang yang tergabung dalam hireraki kepolisian. Sapaan yang dituturkan oleh penutur telah mengalami perubahan kata yang sesuai dengan prinsip kolokial yakni penghilangan kata tanpa merubah makna sebenarnya. Perubahan ini ditandai dengan penghilangan huruf vokal di dalamnya seperti i, u, dan e.

\section{KombesPol (Komisaris Besar Polisi)}

“...Kombes Pol (Komisaris Besar Polisi) Polisi Rastra Gunawan, anda adalah Karo SDM ya di polda jawa timur. Jadi anda tau persis personil anda seperti apa, mengapa sampai harus dipanggil pak tito."

Data di atas merupakan tururan yang disampaikan oleh presenter talk show pada acara stasiun televisi swasta. Data tersebut merupakan sebuah pertanyaan yang ditujukan oleh narasumber pada acara tersebut secara lisan. Nada dan ragam bahasa yang ada ada data tersebut ialah santai dan bersifat semi formal. Norma yang ditunjukkan oleh pelaku turu pada data di atas diperlihatkan pada saat penyebutan pangkat atau jabatan narasumber sebagai bentuk rasa hormat.

Kombes Pol merupakan sebuah jabatan atau pangkat yang dipakai dalam institusi kepolisian yang digunakan demi bentuk sapaan terhadap seseorang pada level tertentu di institusi kepolisian. Pada sapaan tersebut yang dilakukan oleh penutur pada data ini mengalami penglihangan huruf vokal saja antara lain a dan i pada kata sebenarnya. Hal tersebut menyebabkan penyigkatan sebuah kata dalam ucapan sesuai dengan prinsip kolokial.

\section{Brigjen (Brigadir Jendral)}

"Serah terima jabatan di Polda Kalbar juga telah dilakukan di mapolda kabarnya kehadiran Brigjen (Brigadir Jendral) Sri Handayani di Kalimantan barat dianggap menjadi warna baru di tubuh Polda Kalbar. “

Partisipan yang berperan sebagai pelaku tutur dalam data di atas ialah presenter berita. Presenter berita ini berusaha menginformasikan adanya kahadiran seorang anggota kepolisan di sebuah tempat baru secara lisan. Nada serta ragam bahasa yang digunakan dalam peristiwa tutur ini ceria dan bersifat formal. Etika yang ditunjukkan oleh palaku tutur dalam data ini dapat dilhat dari penyebutan pangkat atau jabatan seseorang yang sedang diberitakan.

Pada bentuk sapaan di data ini, diperoleh dari penutur ketika menyebutkanya secara lisan. Data ini berupa sebuatan Brigjen yang telah megalami perubahan kata dengan 
menghilangkan huruf vokal a di dalamnya. Proses perubahan kata tersebut menyebakan penyingkatan kata yang bilamana disandingkan dengan prinsip kolokial akan senada.

\section{Irjen pol (Inspektur Jendral Polisi)}

"Ya kevin egan baru saja 30 menit yang lalu divisi humas mabes polri melalui kadiv humas mabes polri Irjen pol (Inspektur Jendral Polisi)Ronny sompie menyebutkan bahwa pertamatama kepolisian Republik Indonesia menyampaikan berbelasungkawa atas tewasnya salah satu anggota kepolisian..."

Pada data di atas reporter berperan sebagai pelaku tutur yang berusaha menginformasikan kejadian pada data di atas secara lisan. Reporter diberi intruksi oleh presenter yang juga merupakan pelaku tutur untuk membicarakan atas informasi yang di dapat terkait berita yang dibicarakan. Ragam bahasa yang digunakan terkesan formal. Norma atau etika yang ditunjukkan oleh pelaku tutur dalam data ini berupa penyebutan pangkat atau jabatan seseorang yang sedang diberitakan.

Penghilangan huruf vokal $\mathrm{u}$ dan a terilihat pada sapaan terhadap jabatan anggota kepolisian dengan "Irjen Pol" yang disampaikan oleh penutur. Hal ini disampaikan penutur demi menghormati kedudukan atau suatu jabatan yang disandang oleh objek yang sedang dibicarakan. Penghilangan huruf tersebut menyebabkan penyingkatan pada kata awal, yang juga mampu memperrmudah dalam pengucapannya lantaran kepraktisan tersebut. Hal ini merupakan ciri prinsip kolokial yang menekankan pada segi kepraktisan dalam pengucapan.

\section{Komjen (Komisaris Jendral)}

“...menurut, Wakapolri Komjen (Komisaris Jendral) Syafrudin saat ini sudah 33 orang anggota teroris tewas dan ditangkap. pelaku penyerangan mapolda Riau tersebut termasuk dalam kelompok jemaah jamaah anshar daulah."

Data di atas dikemukakan oleh penutur yang merupakan presenter berita di sebuah stasiun televesi. Berita tersebut disampaikan secara lisan dengan tujuan menginformasikan penangkapan terhadap pelaku yang terlibat dalam permasalah yang terdapat pada data di atas. Ragam bahasa yang digunakan yakni formal. Terlihat etika yang ditunjukkan oleh pelaku tutur dengan memperlihatkan rasa hormat pada suatu profesi dengan menyebut pangkat atau jabatan dalam bidang profesi tersebut.

Pada sapaan Komjen yang dikemukakan oleh penutur sebagai bentuk penanda tingkatan seseorang dalam hierarki kepolisian. Komjen telah mengalami perubahan kata yang ditandai dengan penghilangan huruf vokal seperti a dan i yang menyebabkan variasi kolokial di dalamnya.

\section{Penghilangkan Huruf Konsonan dalam Sebuah Kata}

Pada suatu peristiwa tutur tentu saja terdapat peran faktor-faktor di luar bahasa yang menjadi penentu terjadinya peristiwa tutur. Faktor-faktor di luar bahasa ini tergabung dalam interaksi SPEAKING yang memuat rangkain proses penghasil suatu tindak tutur. Hal ini dapat dikaitkan dengan variasi bahasa kolokial yang mendukung ada suatu perubahan pada suatu kata yang menjadi bentuk pengaruh dari adanya faktor di luar bahasa tersebut. Berikut akan dipaparkan terkait terapan interkasi SPEAKING pada variasi bahasa kolokial yang mengalami penghilangan huruf konsonan. 


\section{Bharada (Bhayangkara Dua)}

"Satu anggota Brimob dari kelapa dua Depok Jawa barat Bharada (Bhayangkara Dua) Doni Priyanto gugur dalam kejadian kontak senjata yang berlangsung selama dua setengah jam ini.“

Pada data di atas pelaku tutur yang terlibat yakni presenter berita. Presenter berita ini berusaha menyampaikan informasi terkait berita duka yang tengah terjadi secara lisan. Ragam bahasa yang digunakan mengisyaratkan duka dan bahasanya tetap formal. Etika yang terihat pada data ini terlihat ketika pelaku tur mengucpakan pangkat atau jabatan yang dimiliki oleh seseorang yang sedang dibicarakan sebagai bentuk rasa mengahargai terhadap bidang profesi seseorang.

Bharada merupakan suatu jabatan atau pangkat yang berasal dari penutur demi menunjukkan suatu kedudukan pada hierarki kepolisian. Pada data Bahrada ini telah mengalami proses penyingkatan yang sesuai dengan prinsip kolokial. Prinsip kolokial ini terlihat dari penyingkatan kata dengan penghilangan beberapa huruf vokal antara lain yakni $g, k, n, r$ dan $y$.

\section{AIPDA (Ajun Inspektur Polisi Dua)}

“...kepolisian masih terus mencoba mengungkap apakah motif dari penembakan ini mirip dengan yang terjadi dengan penembakan terhadap anggota kepolisian sebelumnya misalnya di Jakarta pusat, AIPDA (Ajun Inspektur Polisi Dua) Patah Saktiyono yang mengalami luka tembak..."

Data di atas disampaikan oleh pelaku tutur yang merupakan seoarang reporter. Reporter ini berusaha menginformasikan terkait kejadian yang sedang dibicarakan. Reporter berita ini dalam melakukan peristiwa tutur secara lisan diintruksikan terlebih dahulu oleh presenter televisi. Pada saat dalam bertutur yang ditunjukkan pada data di atas dilihat dari pengucapan suatu gelar profesi seseorang.

Pada data AIPDA yang dilafalkan oleh penutur terjadi proses pembentukan kata baru dengan penghilangan huruf konsonan yang terdiri dari $j, k, n, s$, dan $t$ di dalamnya. Hal tersebut terjadi lantaran demi mempersingkat pelafalan sebenarnya tanpa merubah makna yang sesuai dengan prinsip kolokial.

\section{BRIPDA (Brigadir Polisi Dua)}

“....ada BRIPDA (Brigadir Polisi Dua) Ahmad Maulana dan AIPTU (Ajun Inspektur Polisi Satu) kushendratna yang tewas pada kejadian tersebut."

Pada data di atas pelaku tutur ialah seorang reporter berita yang menyampaikan secara lisan setelah mendapat intruksi langsung dari presenter berita di studio. Pelaku tutur pada data di atas berusaha menyampaikan berita yang telah dikumpulkan. Gaya bahasa yang digunakan menggunakan bahasa formal. Norma yang terlihat pada peristiwa tutur di atas terlihat dari rasa menghargai seseorang tehadap profesinya dengan menyebutkan gelar yang berupa jabatan atau pangkat.

BRIPDA merupakan pelafalan yang dikemukakan oleh penutur dalam bahasan kali ini mengalami proses perubahan kata yang ditandai dengan adanya penghilangan huruf konsonan yakni $g$, $l$, dan $s$. Proses penghilangan huruf konsonan pada jabatan tersebut dilakukan demi mempermudah penuturnya pada saat melafalkannya, hal ini sesuai dengan prinsip variasi bahasa kolokial.

\section{BRIPKA (Brigadir Polisi Kepala)}

"Terkait penembakan yang menewaskan BRIPKA (Brigadir Polisi Kepala) Sukardi Selasa malam 10 September mabes polri menggelar 
konfersi pers, dan untuk mengatahui perkebanganya sudah ada satu reporter karlos maikel di mabes polri.“

Pada data di atas partisipan yang berperan ialah presenter berita. Secara lisan presenter berita menyampaikan berita yang terkaitnya dengan kematian anggota kepolisian. Bahasa yang digunakan sesuai dengan bahasa berita pada umumnya yakni formal. Penyebutan nama seseoarang dengan disertai gelar profesinya pada data ini merupakan bentuk etika yang dilakukan oleh pelaku tutur.

Penghilangan huruf konsonan $d, g, l$, dan $s$ pada penyebutan sebuah jabatan yang dilakukan oleh penutur terhadap jabatan BRIPKA. Proses penghilangan huruf konsonan pada jabatan tersebut dilakukan demi menghasilkan sebuah kata baru yang lebih praktis tanpa merubah makna awal, serta mampu mempermudah penuturnya pada saat melafalkannya.

\section{AIPTU (Ajun Inspektur Polisi Satu)}

“...ada BRIPDA (Brigadir Polisi Dua) Ahmad Maulana dan AIPTU (Ajun Inspektur Polisi Satu)kushendratna yang tewas pada kejadian tersebut."

Data di atas berlangsung atas hadirnya pelaku tutur yakni presenter dan reporter sebuah acara berita. Pada tuturan kali ini reporter yang memaparkan secara lisan terkait informasi yang didapat setelah mendapat kesempatan berbicara dari presenter berita di studio. Pada data di atas dikemukakan dengan bahasa berita yakni bahasa formal. Norma atau etika yang terlihat pada data ini diperlihatkan dari pengucapan gelar pangkat atau jabatan yang diemban oleh anggota kepolisian yang tewas.

AIPTU pada bahasan kali ini merupakan penyebutan sapaan atau jabatan yang dilakukan oleh penutur terhadap objek yang menempati posisi tersebut yang sedang dibicarakan. Pada sapaan tersebut telah mengamali proses penghilngan huruf $j, k, n, r$, dan $s$ demi mepersingkat dan mempermudah pelafalan yang dilakukan oleh penutur.

\section{Ipda (Inspektur Polisi Dua)}

"Ipda (Inspektur Polisi Dua)Anumerta auzar sore dimakamkan di tempat pemakaman umum"

Data di atas menunjukkan suatu peritiwa tutur yang melibatkan pelaku tutur yakni seorang presenter berita. Presenter berita ini bertujuan menyampaikan informasi berupa berita duka bagi institusi kepolisian. Pada data di atas disampaikan secara lisan dengan nada yang sedikit merendah dan menggunakan bahasa formal secara lisan. Penyebutan pangkat atau jabatan yang dilakukan pada peristiwa tutur merupakan perilaku etika dalam bertutur yang mengungkapkan rasa hormatnya akan kedudukan seseorang dalam bidang profesinya.

Pada data sapaan Ipda yang merupakan suatu pangkat atau jabatan yang dimiliki oleh seseorang yang tergabung dalam hierarki kepolisian. Sapaan ini digunakan oleh penutur sebagai bentuk rasa hormat terhadap profesi seseorang. Pada data tersebut terlihat penghilangan huruf konsonan seperti $n, r, k$, dan $s$ yang mampu mempersingkat kata sebenarnya. Hal ini sesuai dengan prinsip kolokial yang mengedepankan segi kepraktisan dalam penggunaannya.

\section{KOMPOL (Komisaris Polisi)}

“...tapi polri tetep pernah memberikan surat ya surat pembatalan artinya surat kepada KPK bahwa untuk KOMPOL (Komisaris Polisi)Rossa tidak ditarik dan kemudian juga artinya bahwa sampai saat ini kita juga belum belum menerima surat tersebut dari KPK." 
Data di atas merupakan sebuah berita yang disampaikan oleh pelaku tutur yang merupakan anggota kepolisian. Pelaku tutur pada data di atas memberikan keterangan yang berhubungan dengan peristiwa yang sedang terjadi. Palaku tutur mendapat kesempatan untuk melakukan peristiwa tutur setelah mendapat pertanyaan yang dilontarkan oleh pelaku tutur lainya yakni reporter berita yang sedang bertugas. Ragam bahasa yang digunakan pada peristiwa tutur ini menggunakan bahasa semi formal. Bentuk norma atau etika yang diperlihatkan oleh penutur dapat dilihat dari penyebutan pangkat atau jabatan terhadap rekan yang tergabung dalam intitusi yang sama.

Pada data kata sapaan KOMPOL yang menunjukkan suatu kedudukan seseorang dalam hierarki kepolisian. Sapaan KOMPOL ini diungkapkan oleh penutur sebagai bentuk rasa horamta dan menhargai profesi seseorang yang sedang dibicarakan. Pada data terlihat pengaruh kolokial yang mengurangi atau mempersingkat kata. Hal tersebut dapat dibuktikan dengan penghilangan huruf konsonan pada kata yakni antara lain $r$ dan $s$.

\section{AKBP (Ajun Komisi Besar Polisi)}

“...tertanggal 2 September 2019 Kapolres Pekalongan kota yang AKBP (Ajun Komisi Besar Polisi)Ferry sandi Sitepu diangkat dalam jabatan baru sebagai wakil direktur kepolisian perairan dan udara atau Wadir polair Polda Jateng."

Data di atas melibatakan pelaku tutur yakni presenter berita stasiun televisi swasta. Berita ini dikemukakan oleh pelaku tutur dengan tujuan menginformasikan atas amanah baru terhadap seorang anggota kepolisian di tempat baru. Nada dan Ragam bahasa yang digunakan dalam peristiwa tutur pada data ini stabil dengan sifat formal. Norma atau etika dalam bertutur yang diperlihatkan oleh pelaku tutur dapat dibuktikan dengan penyebutan pangkat atau jabatan sebagai bentuk rasa menghargai pada suatu kedudukan di dalam profesi seseorang.

AKBP merupakan sebuah kata yang telah mengalami proses pembentukan kata. Proses tersebut dapat dilihat dari penghilangan huruf konsonan seperti $j, m, n, r$, dan $s$. Data ini dikemukakan oleh penutur demi menunjukkan suatu jabatan atau pangkat yang dimiliki oleh seseorang pada hierarki kepolisian.

\section{Brigjen (Brigadir Jendral)}

"Serah terima jabatan di Polda Kalbar juga telah dilakukan di mapolda kabarnya bu kemarin kehadiran Brigjen (Brigadir Jendral) Sri Handayani di Kalimantan barat dianggap menjadi warna baru di tubuh Polda Kalbar. “

Pelaku tutur pada peristiwa tutur yang tertera pada data di atas yakni presenter berita. Pelaku tutur pada data ini bertujuan menginformasikan adanya kahadiran seorang anggota kepolisan pada kantor kepolisian di kota kalbar secara lisan. .Nada dan ragam bahasa yang pada peristiwa tutur ini terkesan ceria dan bersifat formal yang menunjang isi pemberitaan berita lantaran berita yang dibawakan termasuk ke dalam suasanan suka cita. Etika dalam bertutur yang ditunjukkan pada data ini dapat dilihat dari penyebutan pangkat atau jabatan seseorang yang sedang diberitakan.

Pada data Brigjen yang diungkapkan oleh penutur ini termasuk dalam variasi bahasa kolokial.hal ini dapat dilihat dari keselarasannya dengan prinsip kolokial yakni terjadi penyingkatan pada suatu kata. Hal ini dapat dibuktikan dengan terjadi penghilangan huruf konsonan d dan 1 . 


\section{Irjen pol (Inspektur Jendral Polisi)}

"Ya kevin egan baru saja 30 menit yang lalu divisi humas mabes polri melalui kadiv humas mabes polri Irjen pol (Inspektur Jendral Polisi)Ronny sompie menyebutkan bahwa pertamatama kepolisian Republik Indonesia menyampaikan berbelasungkawa atas tewasnya salah satu anggota kepolisian..."

Data di atas yang berperan sebagai pelaku tutur yakni reporter berita. Pelaku tutur pada data di atas menginformasikan kejadian yang sedang dibicarakan secara lisan. Reporter mulai menjalankan tugasnya dalam bertutur setelah memperoleh intruksi dari presenter yang juga merupakan pelaku tutur. Ragam bahasa yang digunakan ialah formal. Norma serta etika yang ditunjukkan dengan penyebutan pangkat atau jabatan seseorang yang sedang diberitakan, sebagai bentuk rasa hormat pada bidang profesi seseorang.

Proses penghilangan huruf konsonan $\mathrm{d}, \mathrm{k}$, dan s pada penyampaian jabatan Irjen pol. Penutur dalam data ini menggunakan kata irjen pol untuk menghormati seseorang yang ada dalam posisi tersebut, yang tidak lain merupakan bagian dari hierarki kepolisian. Adapaun perupabahan kata tersebut terjadi demi mempersingkat dan melihat kepraktisan dalam pelafalannya oleh penutur yang mampu memperrmudah penutur nantinya. Hal ini sesuai dengan prinsip kolokial yang mengedepankan segi kepraktisanya.

\section{Komjen (Komisaris Jendral)}

“...menurut, Wakapolri Irjen pol (Inspektur Jendral Polisi)Syafrudin saat ini sudah 33 orang anggota teroris tewas dan ditangkap. pelaku penyerangan mapolda Riau tersebut termasuk dalam kelompok jemaah jamaah anshar daulah.”
Pada data di atas melibatkan penutur yang merupakan presenter berita di sebuah stasiun televisi. Berita tersebut diungkapkan secara lisan dengan tujuan demi menginformasikan terkait penangkapan terhadap seseorang yang terlibat pada permasalah yang sedang dibicarakan. Ragam bahasa yang dikemukakan yakni menggunakan bahasa formal. Etika dan norma yang ditunjukkan oleh pelaku tutur diperlihatkan dengan rasa hormat pada suatu profesi dengan diikuti menyebut pangkat atau jabatatan dalam bidang profesi tersebut.

Komjen merupakan pangkat atau jabatan pada hireraki kepolisian yang menjadi penentu letak suatu kedudukan seseorang. Penutur pada data ini melakukan peristiwa tutur dengan melalui proses pembentukan kata sebelumnya. Hal tersebut dapat dilihat dari penghilangan beberapa huruf konsosnan seperti $d . \quad l, \quad r$ dan $s$ yang otomatis menggolongkannya dalam variasi kolokial yang mengedepankan segi kepraktisan dalam pengucapanya.

\section{Penggunaan Suku Kata Awal dan Akhir pada Sebuah Kata}

Terjadinya suatu tindak tutur tentu saja tidak lepas dari faktor-faktor di luar bahasa yang membawa pengaruh di dalamnya. Hal tersebut dapat mempengaruhi proses pembentukan suatu kata sebagai bentuk adaptasi dengan apa-apa yang terdapat dalam faktor di luar bahasa, sehingga dapat menghasilkan variasi baru bahasa seperti bahasa kolokial yang terbentuk setelah mengalami proses pembentukan kata dengan mengambil salah satu suku kata awal dan akhir pada kata. Berikut akan dipaparkan terapan faktor di luar bahasa pada variasi kolokial:

\section{AIPTU (Ajun Inspektur Polisi Satu)}

“...ada BRIPDA (Brigadir Polisi Dua)
Ahmad
Maulana
AIPTU
(Ajun 
Inspektur Polisi Satu) kushendratna yang tewas pada kejadian tersebut."

Pada data di atas yang berperan sebagai pelaku tutur yakni ialah presenter serta reporter berita pada sebuah acara di salah satu stasiun televisi swasta. Pada data di atas reporter sebagai pelaku tutur, mendapat kesempatan untuk melakukan peristiwa tutur setelah intruksi dari presenter berita didapat. Repoter berita tersebut menyampaikan berita dengan ragam bahasa dan gaya khas berita yang formal. Berita yang disampaikan tergolong ke dalam kategori informasi. Pada data ini bisa terlihat etika atau norma yang ditujukkan dengan menyebutkan nama seseorang yang sedang dibicarakan dengan disertai gelar pangkat atau jabatan yang diemban oleh anggota kepolisian yang tewas.

Pada kata AIPTU yang dikemukakan oleh penutur pada bahasan kali telah mengalami proses pembentukan kata. Kata AIPTU berasal dari kalimat yang terdiri dari beberapa kata Ajun Inspektur Polisi Satu, kemudian kalimat tersebut mengalami perubahan wujud kalimat yang mengambil suku kata awal dan akhir hingga terbetuk lah kata AIPTU. Adapun tujuan dari penutur dalam rmelafalkan kalimat tersebut demi menujukkan suatu hierarki dalam kepolisian.

\section{KOMPOL (Komisaris Polisi)}

“...tapi polri tetep pernah memberikan surat ya surat pembatalan artinya surat kepada KPK bahwa untuk KOMPOL (Komisaris Polisi)Rossa tidak ditarik dan kemudian juga artinya bahwa sampai saat ini kita juga belum belum menerima surat tersebut dari KPK."

Pada data di atas pelaku tutur dalam peristiwa tutur tesebut yakni seseorang yang merupakan bagaian dalam institusi kepolisian. Pelaku tutur pada data di atas memberikan keterangan yang berhubungan dengan peristiwa yang terkait dengan permasalahan rekannya sebagai sesama anggota dalam institusi kepolisian. Tuturan yang dikemukakan oleh pelaku tutur terjadi lantaran adanya campur tangan lain yakni reporter yang meminta keterangan pada pelaku tutur. Ragam bahasa yang dipakai dalam peritiwa tutur ini yakni bahasa semi formal. Bentuk etika yang diperlihatkan oleh penutur pada data di atas dilihat dari penyebutan pangkat atau jabatan teman sesama rekannya dalam institusi kepolisian.

KOMPOL yang dikemukakan oleh penutur ini terdiri dari dua gabungan kata yang kemudian tergabung menjadi satu kata. Hal tersebut dilakukan dengan proses penggabungan suku kata awal pada setiap kata. Dua kata awal yakni komisaris jendral dan kemudian diambil setiap suku kata awal mejadi KOMPOL. Proses perubahan kata ini terjadi lantaran segi keparktisan dalam pengucapanya selaras dengan prinsip kolokial.

\section{KombesPol (Komisaris Besar Polisi)}

“...KombesPol (Komisaris Besar Polisi) Polisi Rastra Gunawan, anda adalah Karo SDM ya di polda jawa timur. Jadi anda tau persis personil anda seperti apa, mengapa sampai harus dipanggil pak tito."

Data di atas merupakan tururan yang melibatkan pelaku tutur yakni presenter talk show pada acara di salah satu stasiun televisi swasta. Pada data di atas percakapan yang dibawakan tergolong pada sebuah pertanyaan yang ditujukan untuk narasumuber pada acara tersebut secara lisan. Nada dan ragam bahasa yang ada pada data tersebut terkesan santai dan bersifat semi formal. Norma atau etika dalam bertutur pada data di atas diperlihatkan pada saaat penyebutan pangkat atau jabatan oleh narasumber sebagai bentuk rasa hormat terhadap kedudukan dalam profesi yang diemban oleh narasumber. 
Pada data di atas Kombes pol merupakan kata yang terdiri dari tiga kata yang kemudia mengalami perubahanan dengan mengokohkannya mejadi dua kata yang lebih prakatis. Hal tersebut tentu saja melalaui proses pembentukan kata yang diambil dari suku kata awal pada setiap kata yang tergabung menghasilkan kata yang lebih praktis.

\section{Brigjen (Brigadir Jendral)}

"Serah terima jabatan di Polda Kalbar juga telah dilakukan di mapolda kabarnya bu kemarin kehadiran Brigjen (Brigadir Jendral)Sri Handayani di Kalimantan barat dianggap menjadi warna baru di tubuh Polda Kalbar. “

Pada data di atas partisipan yang berperan sebagai pelaku tutur yakni presenter berita. Presenter berita sebagai pelaku tutur dalam tuturanya sedang menginformasikan adanya kehadiran seorang anggota kepolisian pada institusi kepolisian di kalbar secara lisan. Nada serta ragam bahasa yang digunakan dalam peristiwa tutur yakni terkesan ceria dan bersifat formal demi mendukung isi berita yang sedang dibawakan. Etika dalam bertutur pada data ini data ini dapat dilihat dari penyebutan pangkat atau jabatan seseorang yang sedang diberitakan.

Brigjen pada data yang ternjadi pada bahasan kali ini berasal dari dua gabungan kata yakni Brigadir Jendral. Pada pengucapan yang dilakukan oleh penutur hanya diucapakan satu kata saja. Hal ini menujukkan proses perubahan kata yang mengambil suku kata awal pada setiap kata sehingga menghasilkan kata baru yang lebih praktis yang senada dengan prisnsip kolokial.

\section{Irjen pol (Inspektur Jendral Polisi)}

"Ya kevin egan baru saja 30 menit yang lalu divisi humas mabes polri melalui kadiv humas mabes polri Irjen pol (Inspektur Jendral Polisi)Ronny sompie menyebutkan bahwa pertamatama kepolisian Republik Indonesia menyampaikan berbelasungkawa atas tewasnya salah satu anggota kepolisian..."

Pada data di atas yang berperan sebagai pelaku tutur yakni reporter. Reporter berita ini menyampaikan informasi terkait kejadian pada peristiwa dalam data di atas secara lisan. Repoter mendapat intruksi dari presenter di studio yang juga merupakan pelaku tutur dalam peristiwa tutur demi membicarakan informasi yang didapat terkait berita yang dibicarakan. Ragam bahasa yang digunakan bersifat formal. Norma atau etika yang diperlihatkan oleh palaku tutur dalam data ini pada penyebutan pangkat atau jabatan seseorang yang sedang diberitakan.

Kolokial yang mengambil suku kata awal dalam sapaan tehadap jabatan yang dilafalkan oleh penutur. Terdapat kata yang tebentuk melalui proses tersebut, kata tersebut ialah Irjen Pol yang bentuk aslinya terdiri dari tiga kalimat yakni Inspektur Jendral Polisi yang kemudian dipersingkat dengan mengambil setiap suku kata awal pada kata tersebut. Kata tersebut dituturkan oleh penutur untuk menunjukkan suatu hierarki dalam kepolisian. Semua ini dilakukan demi efisiensi suatu kata agar rmudah dalam pengucapannya sesuai dengan prinsip kolokial.

\section{Komjen (Komisaris Jendral)}

“...menurut, Wakapolri Komjen (Komisaris Jendral)Syafrudin saat ini sudah 33 orang anggota teroris tewas dan ditangkap. pelaku penyerangan mapolda Riau tersebut termasuk dalam kelompok jemaah jamaah anshar daulah."

Data di atas palaku tutur yang terlibat merupakan presenter berita di sebuah stasiun 
televisi. Reporter berita menyampaikan berita secara lisan demi menginformasikan perihal penangkapan seseorang yang terlibat pada permasalah pada data di atas. Ragam bahasa yang dikemukakan menggunakan bahasa yang formal. Etika atau norma yang ditunjukkan oleh pelaku tutur pada data di atas diperlihatkan dengan rasa hormat pada profesi yang diemban oleh seseorang yang dibicarakan dengan menyebut pangkat atau jabatatan dalam bidang profesi tersebut.

Komjen merupakan suatu pangkat atau jabatan pada hierarki kepolisian yang diungkapkan oleh penutur. Komjen terdiri dari dua kata yakni Komisari Jendral yang tergabung menjadi satu. Pembentukan kata ini melalui proses penggabungan suku kata awal pada setiap kata yang kemudian membentuk kata yang lebih praktis.

\section{PEMBAHASAN}

Pada bagian pembahasan akan dipaparkan segala hal ikhwal terkait dengan teori yang menjadi acuan dalam penelitian ini yakni antara lain, varaiasi kolokial dengan model funsional SPEAKING dalam penerapanya pada hierarki kepolisian negara repuplik indonesia. Pada bagian ini akan dipaparkan perbedaan yang ditemukan dari hasil penelitian dengan teori yang ada. Berikut temuan perbedaan data dengan teori yang ada.

\section{Variasi Kolokial}

Masyarakat yang berada di dalam satu wilayah yang sama, memiliki bahasa yang sering digunakan dalam melakukan interaksi, hal tersebut dapat ditandai dengan adanya hubungan timbal balik di dalam kelompok (Miswanto, Jenawi, \& Afrizal, 2018:63)yang membentuk pola baru pada tatanan bahasa. Variasi bahasa baru dapat muncul dari masyarakat yang berasal dari satu wilayah yang sama. Menurut Poedjosoedarmo dalam (Utami, 2007:3) variasi bahasa merupakan bentuk maupun pola yang menyerupai pola umum bahasa induk. Variasi bahasa merupakan hasil interaksi antar individu yang berada dalam ruang lingkup yang sama dan telah menglamai kesepakatan (Nazihah \& Mujianto, 2020:94)sehinga terbentuk suatu kelompok dalam masyarakat.

Macam variasi bahasa yang menjadi fokus dalam penelitian ini ialah bahasa kolokial, yakni varisai yang dipakai dalam kehidupan sehari-hari. Variasi bahasa kolokial ini dapat berupa pembentukan kata baru yang telah mengalami proses penghilangan kata. Kemudian wujud dari variasi bahas kolokial dapat berupa pemendekan kata. Fenomena variasi kolokial ini bukan masuk ke dalam bahasa formal, melaiankan nonformal karena hanya diturkan oleh sesama. Bahasa kolokial berasal dari bahasa asli yang mengalami pemendekan pengucapan tanpa mengubah tatanan sebelumnya.

Pada bahasan kali ini penelitian akan memaparkan mengenai variasi bahasa serta wujud dari variasi bahasa kolokial yang dipengaruhi oleh faktor-faktor diluar bahasa yang dapat mempengaruhi bentuk sabutan dalam hierarki kepolisian Republik Indonesia.

\section{Pembentukan Kata}

Pembentukan merupakan kata asal yang menglami proses morfologis. Proses morfologis sendiri menurut Tsujimura dalam (Nishfullayli, 1995:37)pembentukan kata dapat terjadi dengan 5 cara, yakni: afiksasi, penggabungan (compounding), reduplikasi, pemenggalan (clipping), dan peminjaman (borrowing). Pada bahasan kali ini pembentukan kata yang terlihat menggunakan cara pemenggalan atau penghilangan kata. Kridalaksana dalam (Rumilah \& Cahyani, 2020:82) memaparkan bahwa pada proses pemenggalan ini dapat menghasilkan bentuk baru dalam tatanan bahasa yang berupa kata. Pemenggalan atau penghilangan kata ialah proses penyingkatan yang menetapkan salah 
satu bagian leksem. Berikut pemaparan mengenai pembentukan kata yang menyebabkan varisai baru dalam penggunaan sebutan di dalam hierarki kepolisian Republik Indonesia.

\section{Penghilangan Huruf Vokal dalam Sebuah Kata}

Pada peritiwa tutur tentu saja terdapat faktor-faktor di luar bahasa yang memiliki pengaruh terhadap peristiwa tutur tersebut. Faktor-faktor tergabung dalam teori SPEAKING yang dikemukakan oleh Hymes dalam (Ibrahim, 2009:12). Pada terapanya dalam prinsip kolokial yang mengilakan huruf vokal pada hierarki kepolisian dilihat dari peran faktor-faktor di luar bahasa tersebut yang mampu memberi impresi terhadap penyebutan suatu pangkat atau jabatan dalam institusi kepolisian, semua faktor tersebut seperti Setting dan sense, Tujuan, Act, Key, Instrument, Norma , Genre ini bersinergi dalam proses pembentukan kata terkait objek dalam penelitian ini yakni hierarki kepolisian Republik Indonesia. Hal ini terjadi sebagai bentuk adaptasi dalam pengucapan atau pelafalan pada hierarki kepolisian Republik Indonesia hingga sesuai dengan prinsip kolokial.

Kolokial merupakan bahasa asli yang kemudian mengalami perubahan. Perubahan bisa terjadi dengan penghilngan huruf tertentu. Pada bahasan kali ini perubahan terjadi terhadap kata dengan penghilagan huruf vokal. Huruf vokal merupakan klasifikasi huruf yang di dasarkan pada ada tidaknya suatu hambatan dalam sistem artikulasi. Bunyi huruf vokal diperoleh dari pelonggaranan udara yang keluar dari dalam organ paru-paru tanpa adanya hambatan. Huruf vokal sendiri juga dapat diklasifikasikan dengan beberapa kriteria, diantaranya (1) gerak maju mundur lidah, (2) gerak lidah naik turun, (3) posisi bibir (Putradi, 2016:98). Huruf yang tergolong ke dalam klasifikasi huruf vokla yakni $\mathrm{a}, \mathrm{i}, \mathrm{u}, \mathrm{e}, \mathrm{o}$.

Penghilagan huruf vokal ini mampu menciptakan sebuah kata baru atau bahasa kolokial. Pada bahasan kali ini, objek yang digunakan berupa sebuatan hierarki pada kepolisian yang mengalamai proses penghilangan kata lataran kepraktisan dalam pengucapanya.

\section{Penghilangan Huruf Konsonan dalam Sebuah Kata}

Interkasi SPEAKING pada peristiwa tutur menjadi pemegang kontrol dalam setiap tuturan yang dihasilkan. Pada kaitannya dengan terapan variasi kolokial yang menghilangkan huruf konsonan dalam hierarki kepolisian Republik Indonesia, interkasi SPEAKING berperan sebagai penggerak yang mampu memberi pengaruh terhadap variasi bahasa yang terbentuk. Hal ini terjadi demi menyesuaikan pengucapan atau pelafalan pada hierarki kepolisian Republik Indonesia hingga sesuai dengan prinsp kolokial.

Penghilangan huruf bukan saja pada huruf vokal, namun bisa juga terjadi pada penghilangan huruf konsonan. Pada bahasan kali ini berfokus pada Kolokial di dalam hieraki kepolisian yang juga mengalami penghilagan kata pada huruf konsonan. Huruf konsonan juga sama hal seperti huruf vokal merupakan klasifikasi huruf yang di dasarkan oleh ada tidaknya suatu hambatan dalam sistem artikulasi. Huruf konsonan merupakan huruf yang dihasilkan dari aliran udara yang berasal dari paru-paru yang disertai hambatan pada rongga mulut oleh artikulasi. Huruf konsosnan juga dapat digolongkan jenisnya berdasarkan kriteria sebagai berikut (1) letak titik artikulasi, (2) cara hambatan, serta (3) getaran dari pita suara(Putradi, 2016:99). 
Huruf konsonan yang terdiri dari 21 huruf antara lain, $b, c, d, f, g, h, j, k, l, m, n, p$, $q, r, s, t, v, w, x, y$, dan $z$. Huruf kononan pada jabatan atau pangkat dalam kepolisian ini menghilang dan mengalami kekekalan pada huruf yang dipertahankan menjadi suatu kata baru yang berupa singkatan.

\section{Penggunaan Suku Kata Awal dan Akhir pada Sebuah Kata}

Faktot-faktor di luar bahasa yang tergabung dalam interaksi SEPAKING seperti yang dikemukakan oleh Hyemes dalam (Ibrahim, 2009:12) tentu saja memiliki pengaruh terhadap variasi bahasa kolokial pada penggunaan suku kata awal dan akhir pada suatu kata. Hal ini tentunya dapat dilihat dari segala aspek dalam faktor di luar bahasa yang dapat menjadi pertimbangan dalam pengucapan atau pelafalan pada objek kajian kali ini. Objek kajian dalam penelitian ini yakni pangkat atau jabatan anggota kepolisian yang memiliki penamaan asli yang cukup panjang, setelah melihat segala aspek tersebut terjadilah proses pembentukan kata yang mengambil suku kata awal dan akhir pada objek kajian kali ini.

Kolokial juga dapat terbentuk dari suku kata yang dipunya dalam suatu kata. Suku kata merupakan bagaian dari kata yang diucapkan atau dilafalkan dengan satu hembusan nafas dan pada umumnya terdiri dari beberapa fonem, menurut (Yusliani, Apriliansyah, \& Apriani, 2016: 170) suku kata pada kaidah bahasa Indonesia terdiri dari (1) satu huruf vokal, (2) satu huruf vokal dan satu huruf konsonan, (3) satu huruf konsonan dan satu huruf vokal, (4) satu huruf konsoan, satu huruf vokal, dan satu huruf konsonan, (5) dua huruf konsonan, dan satu huruf vokal, (6) dua huruf konsonan, satu huruf vokal, dan satu huruf konsonan, (7) satu huruf konsonan, satu huruf vokal, dan dua huruf konsonan, (8) tiga huruf konsonan dan satu huruf vokal, (9) tiga huruf konsonan, satu huruf vokal, dan satu huruf konsonan, (10) dua huruf konsonan, satu huruf vokal, dan dua huruf konsonan, serta (11) satu huruf konsonan, satu huruf vokal, dan tiga huruf konsonan.

Pada penelitian ini pembentukan kata kolokial pada hierarki kepolisian negara Republik Indonesia menggunakan sistem pengambilan suku kata awal serta akhir pada sebuah kata. Sistem ini mampu mengefisiensi pelafalan jabatan atau pangkat dalam hierarki kepolisian negara Republik Indonesia. Hal ini bertujuan menciptakan susanana yang akrab di kalangan tertentu seperti objek dalam makalah ini yakni herarki kepolisian negara Republik Indonesia.

\section{SIMPULAN}

Berdasarkan hasil penelitian, diperoleh variasi bahasa kolokial dalam hierarki kepolisian Republik Indonesia. Varaiasi kolokial tersebut terdiri dari (1) kolokial penghilangan huruf vokal dalam sebuah kata, (2) kolokial penghilangan huruf konsonan dalam sebuah kata, (3) penggunaan suku kata awal dan akhir pada sebuah kata yang diterapkan pada penyebutan pangkat atau jabatan seseoarang yang ada dalam hierarki kepolisian Republik Indonesia.

Model fungsional yang yang dipakai menggunakan yakni interkasi SPEAKING yang terdiri dari (1) setting dan sense merupakan tempat dan suasana dalam bertutur, pada penelitian ini beradasarkan objek kajian yang mengarah pada sebuah institusi Kepolisian Republik Indonesia, berupa sebutan pangkat atau jabatan dalam kepolisian, Setting yang tepat pada penelitian ini ialah jaringan internet yang mampu mengakses video-video yang mengandung data dalam penelitian ini, (2) partisipan ialah pelaku tutur dalam sebuah interaksi, partisipan tersebut merupakan penutur yang terlibat dalam video yang di kumpulkan oleh peneliti. Peneliti berperan sebagai pelaku tutur terhadap 
objek yang sedang dikaji, (3) tujuan merupakan penentu arah yang mampu menggiring pastisipan dalam peristiwa tutur, pada penelitian ini tujuan yang diperoleh untuk mengomunikasikan atas pemberitaaan yang melibatkan seseorang yang telibat dengan institusi kepolisian, (4) act dapat diartikan sebagai suatu kesempatan dalam mengutarakan sebuah tuturan, Pada penelitian ini kesempatan yang diperoleh dari interkasi serta tugas yang memang mengharuskan penutur untuk berbicara (5) key adalah nada suara dan ragam bahasa yang dipergunakan dalam menyampaikan suatu tuturan, pada penelitian ini, nada yang digunakan lugas dan tegas dengan menyesuaikan isi beritanya, (6) instrument merupakan alat yang digunakan dalam berkomunikasi, alat yang digunakan dalam menyampaikan peneltian ini berupa tuturan yang diucapak secara lisan, (7) Norma didefinisikan sebagai etika dalam bertutur, hal ini dapat diliat dari perilaku penutur yang menujukkan rasa menghargai tehadap bidang profesi dengan menyebutkan gelar yang mentukan kedekatan sesorang tersebut, (8) Genre terkait mengetahui konteks dalam peritiwa tutur, pada penelitian ini konteks yang dapat dirasakan dalam stuasi formal dan semi formal, bebeda dengan prinsip kolokial yang biasanya diterapkan hanya pada situasi non formal.

Kolerasi antara variasi bahasa kolokial dan model fungsional SPEAKING yang digunakan dalam penelitian ini tehadap hierarki kepolisian Republik Indonesia. Model funsional SPEAKING berperan sebagai suatu sistem yang di membawa segala peranan yang mampu membawa impresi terhadap variasi bahasa kolokial yang mengalami proses pembentukan kata.

\section{DAFTAR PUSTAKA}

Asmara, R. (2015). Basa-Basi dalam Percakapan Kolokial Berbahasa Jawa Sebagai Penanda Karakter Santun Berbahasa. Transformatika, 11(2), 1-30. Diambil dari https://www.cambridge.org/core/product/identifier/CBO9781107415324A009/type/book_p art

Awlia, T. (2019). 22 Pangkat Polisi Republik Indonesia. Diambil 1 Februari 2021, dari detikNews website: https://news.detik.com/berita/d-4841796/22-pangkat-polisi-republikindonesia

Dakwah, J. M., Islam, U., Sunan, N., \& Timur, K. (2018). Volume 4, Nomor 1, 2018. 4.

Hasanah, R. dkk. (n.d.). Kolokial dan Argot dalam Acara Indonesia Lawak Klub (Ilk): Kajian Sosiolinguistik dan Semantik. 1-13.

Ibrahim, A. S. (2009). Kesemestaan Sosiolinguistik - Abdul Syukur Ibrahim-2009.pdf. In Kesemestaan Sosiolinguistik (hal. Abdul Syukur Ibrahim).

Iswatiningsih, D. D. (2016). Etnografi Komunikasi : Sebuah Pendekatan Dalam Mengkaji. SEMINAR NASIONAL PRASASTI (Pragmatik: Sastra dan Linguistik), 38-45.

Miswanto, Jenawi, B., \& Afrizal. (2018). Pola Interaksi Sosial Suku Laut Di Desa Air Sena, Kecamatan Siantang Tengah, Kabupaten Kepulauan Anambas, Provinsi Kepulauan Riau. Handep, 2, 59-76. 
Truncation Use Language Colloquial. 128-153.

Nazihah, W., \& Mujianto, G. (2020). Maksim Kuantitas pada Ragam Kolokial dalam Sentra Pelayanan Publik. Alinea: Jurnal Bahasa, Sastra, dan Pengajaran, 9(2), 85. https://doi.org/10.35194/alinea.v9i2.951

Nishfullayli, S. (1995). Pembentukan Kata: Proses Morfologis pada Gairaigo. 11(3), 296-300.

Putradi, A. W. A. (2016). Pola-Pola Perubahan Fonem Vokal dan Konsonan dalam Penyerapan Kata-Kata Bahasa Asing ke dalam Bahasa Indonesia: Kajian Fonologi. Jurnal Arbitrer, 3(2), 95. https://doi.org/10.25077/ar.3.2.95-112.2016

Putry, M. E. H. (2016). Peristiwa Tutur dalam Mockumentary Malam Minggu Miko. Arkhais Jurnal Ilmu Bahasa dan Sastra Indonesia, 7(1), 15. https://doi.org/10.21009/arkhais.071.03

Rumilah, S., \& Cahyani, I. (2020). Struktur Bahasa, Pembentukan Kata dan Morfem sebagai Proses Morfemis dan Morfofonemik dalam Bahasa Indonesia. Jurnal Pendidikan Bahasa Indonesia, 8, 70-87. Diambil dari http://jurnal.unissula.ac.id/index.php/jpbsi/article/view/11175

Utami, S. S. (2007). Sela Suci Utami. Variasi Bahasa Masyarakat Pesisir Kampung Tambak Wedi Baru, Surabaya: Kajian Sosiolinguistik, 6.

Yusliani, N., Apriliansyah, R., \& Apriani, T. W. (2016). Pemenggalan Kata Dasar Bahasa Indonesia menggunakan Syllabification Algorithm. 4, 169-172. 